\title{
MANUSIA SEBAGAI HOMO ECONOMICUS: REFLEKSI ATAS KASUS-KASUS KEJAHATAN DI INDONESIA
}

\section{Septiana Dwiputri Maharani}

Fakultas Filsafat Universitas Gadjah Mada

Email: septianadm@gmail.com

\section{Abstrak}

Penelitian menunjukkan bahwa Pertama, idealnya setiap manusia dapat melakukan tindakan dalam dwifungsinya sebagai makhluk individu sekaligus sebagai makhluk sosial. Keseimbangan ini sesungguhnya menjadi bantalan bagi bangunan keharmonisan dalam kehidupan masyarakat. Jika terjadi kepincangan, apalagi kecenderungan individu menonjolkan posisi sebagai makhluk individu maka bangunan kehidupan bersama dapat menjadi seperti yang digambarkan dalam homo homini lupus, padahal membangun masyarakat yang harmonis harus didukung dengan kehidupan bersama, saling membutuhkan, dan saling memberi. Kedua, Tindakan kejahatan di Indonesia seperti pembunuhan, korupsi, trafficking, dan sebagainya, merupakan fakta betapa kehidupan di Indonesia sudah dibayang-bayangi oleh kepentingan pribadi yang sangat menonjol. Kepentingan pribadi yang lebih didominasi oleh faktor ekonomi menjadi pengaruh besar dalam kecenderungan tindakan kejahatan. Kecenderungan manusia Indonesia lebih menekankan aspek sosialitasnya, namun ternyata fakta membuktikan bahwa kecenderungan itu sudah mulai memudar, meskipun tidak semua manusia Indonesia melakukan tindak kejahatan. Setidaknya, homo economicus dalam pengertian manusia ekonomi yang senantiasa menekankan aspek keuntungan dalam setiap tindakannya dapat menjadi alat uji dalam realitas kehidupan bangsa Indonesia. Ketiga, Homo economicus benar-benar dipahami dalam suatu tindakan yang kontradiktif dengan pengertian homo Socius. Homo economicus jika tidak dikendalikan akan membawa manusia dalam suatu situasi "berperang" seperti gambaran homo hominilupus.

Kata kunci: kejahatan, norma, homo economicus, homo hominilupus.

\section{Abstract}

This research showed that First, ideally every man should act in a dual functions as individual beings as well as a social being. These dual functions of the real foundation for the building harmony in the life of a society. If lameness, especially the tendency of individuals includes positions as individual beings 
then building a life together can be as depicted in homo homini lupus, but building a harmonious society should be supported by common life, need, and give each other. Secondly, crimes in Indonesia are the fact how life in Indonesia has been overshadowed by very prominent self-interests. Personal interests which dominated by economic factors become a major influence in the crime trend. Indonesian human tendency their societies emphasize some aspects, but it turns out it's a proven fact that trend has begun to fade, al though not all Indonesian people commit crimes. At least, homo economicus could be a tool to test the reality of Indonesian life. Third, Homo economicus is fully understood in an act that contradicts the notion homos socius. Homo economicus if not controlled will lead humanity in a situation of "war" as a Homo Homini Lupus.

Keywords: crime, norms, homo economicus, homo hominilupus.

\section{PENDAHULUAN}

Maraknya kasus kejahatan di Indonesia dewasa ini sering mendominasi berita harian di berbagai media massa. Berbagai kasus tersebut ditangani pihak yang berwenang, untuk mencari akar persoalan alasan seseorang melakukan kejahatan. Media televisi misalnya, mewartakan sejumlah kasus pembunuhan setiap hari, dari mulai kasus pembunuhan orang tua terhadap anaknya, anak terhadap orang tua, suami terhadap istri atau sebaliknya, pembantu melakukan pembunuhan terhadap anak atau keluarga majikannya, bahkan orang melakukan pembunuhan dengan sadis terhadap tetangganya sendiri.

Kasus yang lain adalah merebaknya tindak korupsi oleh sejumlah kaum elit yang seharusnya tunduk dan loyal pada nilai-nilai dan norma yang mengikatnya. Ironisnya adalah mereka yang tertangkap tangan melakukan tindak korupsi kemudian muncul di televisi nasional, dan masyarakat menyaksikan sikap mereka yang masih dapat tersenyum bahkan tertawa. Ini adalah fenomena yang dapat diamati bagaimana nilai yang mereka bangun menjadi kepribadian mereka tersebut.

Berbagai sudut pandang atau perspektif tidak cukup alasan dan tidak bisa melakukan toleransi atas perbuatan 'jahat" seperti yang digambarkan di atas. Bagaimanapun idealnya seseorang melakukan perbuatan atas muatan nilai yang dibangun dalam masyarakatnya. Celakanya adalah mereka hidup di Indonesia yang hidup di atas dasar nilai 
etis dan religius yang tinggi dengan berpedoman pada nilai Pancasila. Rupanya nilai ini tidak menjadikan mereka menjadi warga masyarakat yang ideal yang dapat dijadikan contoh masyarakat.

Gambaran ideal kehidupan manusia yang dipenuhi rasa cinta dan kedamaian sungguh tidak sepenuhnya dapat direalisasikan seluruhnya. Berbagai faktor seperti perbedaan kepentingan, perbedaan status sosial, rasa kepedulian dan empati, penurunan moral, merosotnya nilai-nilai kemanusiaan, merupakan salah satu dari berbagai faktor yang dapat menyebabkan manusia kehilangan kepercayaan diri maupun kepada orang lain dalam upaya membangun kehidupan bersama. Hidup yang mengedepankan individualisme dan mengabaikan kesadaran tentang hidup bersama, hanya akan berpotensi terhadap konflik yang berkepanjangan.

Ada banyak motif sehingga seseorang melakukan kejahatan. Manusia tidak lagi menggunakan dasar moral sebagai ukuran dalam melakukan suatu tindakan. Perbuatan keji misalnya dengan merebut bahkan menindas hak orang lain, merupakan perbuatan yang tidak manusiawi. Ada orang membunuh karena dendam, ada yang melakukannya karena cemburu, ada juga orang melakukan pembunuhan karena gangguan kejiwaan. Beberapa yang lain melakukan pembunuhan terhadap diri sendiri (bunuh diri) atau membunuh orang-orang yang justru sangat dicintai karena putus asa. Ada yang korupsi karena tidak ingin menyia-nyiakan kesempatan, korupssi demi kekayaan pribadi, dan berbagai motif lainnya.

Penelitian ini secara khusus akan mengamati kasus kejahatan di Indonesia dengan menggunakan perspektif Filsafat Manusia. Hasil refleksi nantinya akan digunakan untuk mencari dan menemukan salah satu akar penyebab individu melakukan tindak kejahatan dengan mengaitkan dalam tesis tentang manusia, yaitu Homo Economicus.

\section{DEFINISI KEJAHATAN}

Soesilo mengatakan bahwa kejahatan dibagi dalam dua sudut pandang yaitu yuridis dan sosiologis. Secara yuridis, kejahatan mengandung pengertian perbuatan tingkah laku yang bertentangan de- 
ngan undang-undang (Soesilo, 1985: 1). Secara sosiologis, pengertian kejahatan menurut Soesilo adalah perbuatan atau tingkah laku yang selain merugikan si penderita, juga sangat merugikan masyarakat yaitu berupa hilangnya keseimbangan, ketentraman, dan ketertiban (Soesilo, 1985: 1).

Statuta Roma yang diadopsi dari UU no.28 tahun 2000 tentang pengadilan HAM di Indonesia, Pasal 7 mendefinisikan kejahatan terhadap kemanusiaan yaitu perbuatan yang dilakukan sebagai bagian dari serangan yang meluas atau sistematik yang diketahuinya bahwa serangan tersebut ditujukan secara langsung terhadap penduduk sipil.

Kejahatan menurut B. Simanjuntak adalah suatu tindakan anti sosial yang merugikan, tidak pantas, tidak dapat dibiarkan, yang dapat menimbulkan kegoncangan dalam masyarakat. Van Bammelen mengatakan bahwa kejahatan adalah tidak susila dan merugikan dan menimbulkan begitu banyak ketidaktenangan dalam suatu masyarakat tertentu, sehingga masyarakat itu berhak untuk mencelanya dan menyatakan penolakannya atas kelakuan itu dalam bentuk nestapa dengan sengaja diberikan karena kelakuan tersebut (Yani, 2012:1).

Yani (2012: 1) selanjutnya mengurai beberapa definisi tentang kejahatan sebagai berikut. Kejahatan dalam pandangan J.M. Bemmelem adalah tindakan anti sosial yang menimbulkan kerugian, ketidakpatutan dalam masyarakat, sehingga akan menimbulkan kegelisahan masyarakat, dan untuk menentramkan masyarakat, Negara mempunyai kewajiban untuk memberi hukuman kepada penjahat. Elliot mengatakan bahwa kejahatan adalah suatu problema dalam masyarakat modern atau tingkah laku yang gagal dan melanggar hukum dapat dijatuhi hukurnan penjara, hukuman denda, hukuman mati dan seterusnya.

W.A. Bonger berpandangan bahwa kejahatan adalah perbuatan yang sangat anti sosial yang memperoleh tantangan dengan sadar dari negara berupa pemberian penderitaan. Menurut Paul Moedikdo Moeliono, kejahatan adalah perbuatan pelanggaran terhadap norma hukum yang ditafsirkan atau patut ditafsirkan masyarakat sebagai perbuatan yang merugikan, menjengkelkan sehingga tidak boleh dibiarkan, 
artinya harus ada tindakan dari negara.

Suara yang lain, J.E. Sahetapy dan B. Marjono Reksodiputro dalam bukunya Paradoks Dalam Kriminologi menyatakan bahwa, kejahatan mengandung konotasi tertentu, yang merupakan suatu pengertian dan penamaan yang relatif, mengandung variabilitas dan dinamik serta bertalian dengan perbuatan atau tingkah laku (baik aktif maupun pasif), yang dinilai oleh sebagian mayoritas atau minoritas masyarakat sebagai suatu perbuatan anti sosial, suatu perkosaan terhadap skala nilai sosial dan atau perasaan hukum yang hidup dalam masyarakat sesuai dengan ruang dan waktu.

Istilah kejahatan juga dapat dimengerti dalam arti bahasanya, yaitu Pengertian kriminalitas. Kamus Umum bahasa tertulis, Kriminalitas menurut bahasa adalah sama dengan kejahatan, yaitu pelanggaran yang dapat dijatuhi hukuman, yaitu segala perkara kejahatan yang dapat dihukum menurut Undang-Undang. Sedangkan pengertian kriminalitas menurut istilahnya diartikan sebagai suatu kejahatan yang tergolong dalam pelanggaran hukum positif yakni hukum yang berlaku dalam suatu negara.

Pengertian kejahatan sebagai unsur dalam pengertian kriminalitas, secara sosiologis mempunyai dua unsur-unsur yaitu: 1) Kejahatan itu ialah perbuatan yang merugikan secara ekonomis dan merugikan secara psikologis. 2) Melukai perasaan susila dari suatu segerombolan manusia, di mana orang-orang itu berhak melahirkan celaan. Dengan demikian, pengertian kriminalitas adalah segala macam bentuk tindakan dan perbuatan yang merugikan secara ekonomis dan psikologis yang melanggar hukum yang berlaku dalam negara Indonesia serta norma-norma sosial dan agama.

Oktavian (2013:1) menguraikan tentang pengertian kejahatan dalam kaitan ekonomi, sebagai berikut. Kejahatan adalah suatu pidana atau tindak kriminal terhadap segala sesuatu yang melanggar hukum atau sebuah tindak kejahatan. Pelaku kriminalitas disebut seorang kriminal. Ada sebuatan-sebutan terhadap pelaku yang dianggap kriminal adalah seorang pencuri, pembunuh, perampok, atau teroris. Ranah hukum menjelaskan, selama kesalahan seorang kriminal belum ditetap- 
kan oleh seorang hakim, maka orang ini disebut seorang terdakwa, karena ini merupakan asas dasar sebuah negara hukum atas praduga tidak bersalah, artinya seseorang tetap tidak bersalah sebelum kesalahannya terbukti. Pelaku tindak kriminal yang kemudian dinyatakan bersalah oleh pengadilan dan harus menjalani hukuman disebut sebagai terpidana atau narapidana.

Kejahatan dalam pendefinisian ini, ada beberapa pandangan tentang perbuatan yang dapat dikategorikan sebagai kejahatan. Definisi kejahatan dalam pengertian yuridis tidak sama dengan pengertian kejahatan dalam kriminologi yang dipandang secara sosiologis.

Kejahatan, secara yuridis dapat didefinisikan sebagai suatu tindakan yang melanggar undang-undang atau ketentuan yang berlaku dan diakui secara legal. Kejahatan secara kriminologi yang berbasis sosiologis, merupakan suatu pola tingkah laku yang merugikan masyarakat dan suatu pola tingkah laku yang akan menimbulkan reaksi sosial. Reaksi sosial tersebut dapat berupa reaksi formal, reaksi informal, dan reaksi non-formal.

Oktavian (2013: 1) menuliskan kaitan tindak pidana dengan aspek ekonomi sebagai berikut. Tindak kejahatan, kemungkaran, kemaksiatan, premanisme, dll dalam aspek hukum, adalah perbuatan yang pelakunya dikenakan sanksi hukum, seperti pembunuhan, aborsi, korupsi, dll. Sanksi hukum dapat berupa sanksi hukum agama, hukum adat, dan hukum Negara. Tindak kejahatan menurut Oktavian, secara hukum sifatnya relatif, artinya tergantung dari waktu, tempat, situasi-kondisi, tidak tetap, tidak universal.

Tindak kejahatan dalam aspek sosiologis atau kemasyarakatan adalah perbuatan yang merugikan secara ekonomis dan merugikan secara psikologis, atau melukai perasaan susila/etika/moral. Tindak kejahatan secara sosiologis lebih luas, tetapi juga bersifat relatif, tergantung dari waktu, tempat, situasi-kondisi, tidak tetap, tidak universal. Tindak kejahatan secara sosiologis sebenarnya adalah perbuatan yeng melanggar hukum adat, seperti bermain judi, telanjang dada, sabung ayam, pamer paha, porno aksi, prostitusi, homo, lesbi, kumpul kebo, dan lain-lain. 
Tindak kejahatan itu menurut van Bemmelen, disebabkan karena niat, watak, karakter, sikap mental, dan lingkungan (kesempatan, situasi-kondisi, waktu, tempat, dan lahan). Jaman sekarang ini, orang baikbaik bisa saja berubah menjadi jahat. Mengapa? Karena terdapat hubungan, korelasi antara situasi-kondisi dan tindak kejahatan.

Berpijak pada hasil analisa George Mayr tahun 1835-1861 di Bremen, Jerman, berdasarkan statistik, Oktavian (2013:1) mengatakan bahwa terdapat korelasi antara kenaikan tingkat kejahatan dengan kenaikan harga kebutuhan bahan pokok. Dijelaskan bahwa tingkat kejahatan berhubungan erat dengan tingkat kesenjangan sosial-ekonomi. Artinya, makin tinggi tingkat kesenjangan sosial-ekonomi, maka semakin tinggi pula potensi kejahatan. Oleh karena itu dapat disederhanakan bahwa tingkat kejahatan tergantung dari tingkat kesejahteraan masyarakat.

Tindak kejahatan juga berkorelasi dengan angka pengangguran dalam suatu masyarakat. Semakin banyak pengangguran, maka semakin meningkat tindak kejahatan. Oleh karena itu angka tindak kejahatan dapat diturunkan dengan menurunkan angka pengangguran. Seluruh kebijakan sebaiknya mengaitkan dampak yang mungkin ditimbulkan dengan tindak kejahatan. Kebijakan menaikkan harga misalnya, apakah akan berpengaruh terhadap munculnya tindak kejahatan atau tidak. Kebijakan pemerintah untuk memberikan fasilitas terhadap investor, apakah akan berdampak terhadap kejahatan atau tidak? Bagaimana dengan maraknya tindak korupsi? (Hoetaoeroek, 1961:69).

Kejahatan juga dapat dilihat dalam pengertiannya sebagai kejahatan genosida dan kejahatan kemanusiaan (Kiranawati, 2008:1). Kejahatan genosida merupakan perbuatan yang dilakukan dengan maksud untuk menghancurkan sebagian atau seluruh kelompok bangsa, ras, kelompok etnis, kelompok agama, dengan menggunakan cara-cara sebagai berikut.

1) Membunuh anggota kelompok

2) Mengakibatkan penderitaan fisik atau mental yang berat terhadap anggota kelompok

3) Menciptakan kondisi kehidupan kelompok yang akan mengaki- 
batkan kemusnahan secara fisik baik sebagian atau seluruhnya

4) Memaksakan tindakan yang bertujuan mencegah kelahiran di dalam kelompok

5) Memindahkan secara paksa anak-anak dari kelompok tertentu ke kelompok lain.

Kejahatan kemanusiaan merupakan suatu perbuatan yang dilakukan sebagian dari serangan yang meluas atau sistematik yang diketahui bahwa serangan tersebut ditujukan secara langsung terhadap penduduk sipil, seperti:

1) Pembunuhan

2) Pemusnahan

3) Perbudakan

4) Pengusiran atau pemindahan penduduk secara paksa

5) Perampasan kemerdekaan atau perampasan kebebasan fisik lain secara sewenang-wenang yang melanggar (asas-asas) ketentuan pokok hukum internasional

6) Penyiksaan

7) Perkosaan, perbudakan seksual atau trafficking, pemaksaan kehamilan, pemandulan atau sterilisasi secara paksa atau bentuk-bentuk kekerasan seksual lain yang setara

8) Penganiayaan terhadap suatu kelompok tertentu atau perkumpulan yang didasari persamaan paham politik, ras kebangsaan, etnis, budaya, agama, jenis kelamin atau alasan lain yang telah diakui secara universal sebagai hal yang dilarang menurut hukum internasional

9) Kejahatan apartheid.

Wahyu Ramdhany (2011: 1) memaparkan secara luas tentang pengertian kejahatan sebagai berikut. Manusia sebagai makhluk sosial mengandung makna bahwa setiap individu tidak dapat hidup tanpa adanya bantuan dari orang lain untuk memenuhi kebutuhan hidupnya. Kehidupan bermasyarakat menekankan pentingnya suatu kebutuhan yang merupakan hal pokok untuk dipenuhi, oleh sebab itu banyak individu tertentu yang berlaku konsumtif untuk memenuhi setiap kebutuhan dalam hidupnya, namun disisi lain tindakan menyim- 
pang dari individu tertentu juga merupakan suatu persoalan dan sulit untuk dihadapi. Tindakan yang menyimpang dalam masyarakat inilah yang terkadang menjadi polemik bahkan sulit untuk dihindarkan. Faktor keterbatasan kemampuan ekonomi seorang individu menjadi tuntutan untuk memenuhi kebutuhan hidupnya, sehingga banyak cara yang digunakan untuk dapat memenuhi kebutuhan tersebut. Inilah faktor yang potensial menyebabkan terjadinya suatu tindak kejahatan dalam suatu masyarakat.

Kejahatan merupakan suatu perbuatan yang melanggar hukum pidana atau undang-undang yang berlaku dalam masyarakat. Hakikatnya, suatu perbuatan yang melanggar hukum pidana atau Undangundang yang berlaku dalam suatu masyarakat adalah suatu perbuatan yang sangat merugikan masyarakat yang bersangkutan. Masyarakat seharusnya menyadari bahwa eksistensi suatu hukum dalam masyarakat merupakan pengejawantahan dari tuntutan masyarakat agar jalannya kehidupan bersama menjadi baik dan tertib.

Ramdhany (2011: 1-3) merumuskan pengertian kejahatan dari para tokoh, sebagai berikut.

1) Paul W Tappan: kejahatan adalah The Criminal Law (statutory or case law), commited without defense or excuse, and penalized by the state as a felony and misdemeanor.

2) Huge D Barlow: kejahatan adalah a human act that violates the criminal law.

3) Sutherland: kejahatan adalah perilaku yang dilarang oleh negara karena merupakan perbuatan yang merugikan negara dan terhadap perbuatan itu negara bereaksi dengan hukuman sebagai pamungkas.

4) Bonger:kejahatan merupakan perbuatan anti sosial yang secara sadar mendapat reaksi dari negara berupa berupa pemberian derita dan kemudian sebagai reaksi terhadap rumusan-rumusan hukum (legal definitions) mengenai kejahatan.

5) R. Soesilo membedakan pengertian kejahatan secara yuridis dan pengertian kejahatan secara sosiologis. Ditinjau dari aspek yuridis, pengertian kejahatan adalah suatu perbuatan tingkah laku yang 
bertentangan dengan undang-undang. Sementara dari aspek sosiologis, yang dimaksud dengan kejahatan adalah perbuatan atau tingkah laku yang selain merugikan si penderita, juga sangat merugikan masyarakat yaitu berupa hilangnya keseimbangan, ketentraman dan ketertiban.

6) J.M. Bemmelem: kejahatan sebagai suatu tindakan anti sosial yang menimbulkan kerugian, ketidakpatutan dalam masyarakat, sehingga dalam masyarakat terdapat kegelisahan, dan untuk menentramkan masyarakat, negara harus menjatuhkan hukuman kepada penjahat.

7) M.A. Elliot:kejahatan adalah suatu problem dalam masyarakat modern atau tingkah laku yang gagal dan melanggar hukum dapat dijatuhi hukurnan penjara, hukuman mati dan hukuman denda dan seterusnya.

8) Paul Moedikdo Moeliono: kejahatan merupakan perbuatan pelanggaran norma hukum yang ditafsirkan atau patut ditafsirkan masyarakat sebagai perbuatan yang merugikan, menjengkelkan sehingga tidak boleh dibiarkan (negara bertindak).

9) J.E. Sahetapy dan B. Marjono Reksodiputro dalam bukunya Paradoks Dalam Kriminologi menyatakan bahwa, kejahatan mengandung konotasi tertentu, merupakan suatu pengertian dan penamaan yang relatif, mengandung variabilitas dan dinamik serta bertalian dengan perbuatan atau tingkah laku (baik aktif maupun pasif), yang dinilai oleh sebagian mayoritas atau minoritas masyarakat sebagai suatu perbuatan anti sosial, suatu perkosaan terhadap skala nilai sosial dan atau perasaan hukum yang hidup dalam masyarakat sesuai dengan ruang dan waktu.

\section{MOTIF-MOTIF TINDAKAN MANUSIA}

Motif atau dorongan adalah suatu keinginan/hasrat yang mendorong manusia untuk melakukan suatu tindakan. Motif ekonomi misalnya, merupakan hasrat manusia untuk melakukan tindakan ekonomi. Motif ekonomi didasari setidak-tidaknya oleh: motif untuk mendapatkan kesejahteraan (dorongan untuk mendapat keuntungan), motif un- 
tuk mendapatkan penghargaan, dan motif untuk memperoleh kekuasaan (Agustian, t.t: 1).

Abraham Maslow (Triacute, t.t: 1) membuat hierarki kebutuhan manusia menjadi:

1) Kebutuhan fisik

2) Kebutuhan mendapatkan rasa aman

3) Kebutuhan untuk mendapatkan pengakuan

4) Kebutuhan akan harga diri

5) Kebutuhan akan perwujudan diri.

Marbusan (2011:1) merangkum teori motif sebagai berikut.

1) Humanity Theory

Kejadian kemanusiaan dilatarbelakangi oleh beberapa motif. Misalnya, bencana Tsunami di Aceh menarik perhatian dan kepedulian rakyat Indonesia, untuk tergerak hatinya membantu korban bencana tersebut. Mengapa demikian? Banyak ahli mengatakan bahwa hal ini adalah perwujudan teori kemanusiaan berdasar pada teori Abraham Maslow, yaitu hirarki kebutuhan terutama kebutuhan akan rasa cinta.

Manusia berbicara tentang motif, berarti ia tengah berbicara tentang goal (tujuan). Tidak ada keinginan untuk mendapatkan reward secara normatif dalam arti penyumbang Tsunami Aceh tidak mengharapkan apapun atas bantuannya itu. Hal lain, tidak adanya rasa diuntungkan bagi penerima bantuan. Korban Tsunami Aceh yang kehilangan keluarganya tidak serta merta merasa bahagia dengan mendapatkan bantuan, juga hampir tidak berpeluang untuk mengais rejeki dari kemalangan tersebut, artinya tidak mencari kesempatan atas bantuannyaitu.

2) Arousal Theory

Hampir sama dengan Teori Drive Reduction dari Clark Hull, teori ini menyatakan bahwa manusia cenderung mempertahankan rasa nyaman dari gangguan yang ada, seperti gangguan emosional, intelektual atau bahkan tindakan. Misalnya melakukan tindakan peduli terhadap musibah yang menimpa orang lain didasari oleh suatu perasaan pengandaian hal tersebut menimpa dirinya, sekali- 
gus menghindarkan diri dari musibah tersebut. Contohnya: gerakan mengumpulkan koin untuk bayi penderita kelainan hati. Secara singkat Arousal Theory bukanlah suatu gerakan kemanusiaan yang murni, namun lebih berdasar pada suatu misi /goal yang ingin dicapai, misalnya bagi keluarga terbantu menjadi terkenal, sementara yang membantu mendapat predikat memiliki kepekaan atau kepedulian yang tinggi.

3) Eros dan Thanatos Theory

Freud mengemukakan teori psikoanalisa dimana seringkali tindakan manusia didasari oleh eros dan Thanatos, atau dorongan hidup dan dorongan kematian. Misalnya dorongan untuk membantu pasien yang akan melakukan transplantasi hati yang sudah disiarkan oleh TV. Kaum Psikoanalis berpendapat bahwa tindakan manusia sehari-hari merupakan upaya untuk melestarikan kehidupan dan mencegah kerusakan pada kehidupan manusia.

Beberapa perspektif juga yang bisa digunakan untuk melihat motif tindakan manusia, yaitu:

1) Perspektif neurobiologi

Tingkah laku manusia pada dasarnya dikendalikan oleh aktivitas otak dan sistem syaraf, sehingga perilaku seseorang tergantung pada kondisi otak dan sistem syarafnya, bila otak dan syaraf terganggu maka akan terganggu juga perilakunya. Penemuan-penemuan penelitian telah menunjukkan bahwa ada hubungan yang sangat erat antara aktivitas otak dengan perilaku dan dengan pengalaman. Misalnya, reaksi emosi, seperti rasa takut dan marah, pada hewan dan manusia dapat dirangsang dengan aliran listrik lemah di daerah tertentu yang jauh di bagian dalam otak.

2) Perspektif psikoanalisis

Setiap tindakan manusia senantiasa mempunyai sebab, namun seringkali berupa motif-motif yang tidak disadari, bukan alasan rasional yang diberikan oleh seseorang terhadap perilakunya. Pandangan psikoanalis menilai kepribadian manusia merupakan interaksi antara id, ego, dan superego. 
3) Perspektif perilaku

Perilaku manusia hanya berdasarkan perilaku yang tampak dan dapat diukur. Perilaku manusia pada dasarnya adalah respon atas stimulus yang datang dan merupakan hasil dari proses belajar. Manusia belajar dari lingkungannya dan dari hasil belajar itulah ia berperilaku. Oleh karena itu, manusia dapat dipengaruhi oleh lingkungannya.

4) Perspektif Kognitif

Manusia bukan hanya penerima stimulus yang pasif. Mental manusia mengolah informasi yang diterimanya dan mengubahnya menjadi bentuk-bentuk baru dan memilihnya ke dalam kategorikategori.

5) Perspektif humanistik

Dengan mempertimbangkan: (i) keunikan manusia, (ii) pentingnya nilai dan makna, (iii) kemampuan manusia untuk mengembangkan diri. Jadi, pendekatan ini menilai manusia tidak digerakkan oleh kekuatan luar yang tidak dapat dikontrolnya, tetapi manusia adalah pemeran yang mampu mengontrol nasib sendiri dan mampu mengubah dunia di sekelilingnya.

\section{FENOMENA TINDAK KEJAHATAN DI INDONESIA}

Indonesia merupakan salah satu negara di dunia yang memiliki keberagaman, baik secara etnis, letak geografis, adat, bahasa, agama, dan kultur. Kemajemukan ini rupanya berpengaruh pada ragam tindak individu dalam menghadapi atau menyikapi hidup. Keragaman tindakan pada hakikatnya dilandasi oleh motif tertentu dan tujuan tertentu pula.

Segala tindakan akan diatur dalam setiap norma yang sudah menjadi konsensus bagi masyarakat setempat. Baik dan buruk menjadi ukuran bagi setiap tindakan, yang diukur berdasar standar nilai yang disepakati. Suatu tindakan disebut baik apabila tindakan yang dilakukan merupakan suatu tindakan yang mematuhi koridor nilai, sementara tindakan buruk adalah tindakan yang dilakukan menyimpang dari nilai yang disepakati sebagai baik. 
Motif tindakan menjadi keunikan bagi tindakan setiap individu. Tindakan tersebut menjadi fakta bahwa realitas dalam sebuah masyarakat menghasilkan beragam tindakan, yang tentu saja berkorelasi pada aspek-aspek yang lain, misalnya pengaruh budaya, ekonomi, agama, hukum, dsb.

Berikut akan diuraikan ragam tindakan manusia yang justru merupakan tindakan menyimpang dari konsensus masyarakat pada umumnya. Ragam tindakan berikut dapat dianalisa mengapa individu dapat melakukan tindakan tersebut dalam masyarakatnya.

1) Pembunuhan

Tindakan membunuh dapat disebabkan oleh beberapa alasan, seperti: dendam, kekhawatiran/ketakutan yang berlebihan, malu, putus asa (terutama pada kasus bunuh diri), faktor keterbatasan ekonomi, jobless, mempertahankan nyawa sendiri, mempertahankan harga diri, stress, dll. Sebuah media elektronik mengabarkan seorang pemuda berumur 20 tahun, pendiam dan pemalu menjadi pembunuh berdarah dingin yang tega membantai bocah-bocah tidak berdosa. Disinyalir perbuatannya itu dipengaruhi oleh ibunya yang mengidap paranoid. Pemuda tersebut diketahui mengidap Sindrom Asperger, sejenis autisme. Oleh teman-temannya, pemuda yang bernama Adam Lanza ini dikatakan sebagai anak yang sangat cerdas, namun sulit bersosialisasi (Armandhanu, 2013:1).

Pembunuhan dapat terbagi dalam pebunuhan berencana dan pembunuhan spontan. Ragamnya banyak, seperti misalnya membunuh orang lain, mutilasi, bunuh diri, yang setiap tindakan tersebut mempunyai alasan tertentu, termasuk alasan "yang penting ada korban". Pembunuhan juga bisa dilakukan oleh orang yang memiliki kelainan orientasi seksual, seperti yang dilakukan oleh Ryan, pemuda yang menggemparkan masyarakat pada tahun 90an, telah melakukan pembunuhan berantai, dan diketahui memiliki motif ekonomi (anonim, t.t, dalam http://www.i2harmony.info/ tiga-pembunuh-berlatar-belakang-kelainan-orientasi-seksual. html).

Pembunuhan merupakan salah satu tindakan kejahatan yang 
dapat dijelaskan dalam konsep homo economicus. Motif yang sangat beragam seperti dendam, keinginan memiliki barang dari si korban, kelainan seksual, mendapatkan keuntungan secara materi, atau menenangkan diri dari suatu ancaman yang membuat hidupnya tidak tenang. Tindakan membunuh sangat berbahaya karena melanggar nila kemanusiaan, apalagi korban sebenarnya tidak ada hubungan sama sekali dengan si pelaku.

2) Penipuan dan perampasan

Tindakan penipuan dan perampasan, bahkan perampokan yang dilakukan oleh seseorang atau sekelompok orang, lebih cenderung dimotivasi oleh keterbatasan ekonomi, sehingga tindakan tersebut dilakukan karena ada kecenderungan individu mempertahankan hidup. Pertahanan hidup perlu dan memang disepakati, harus dengan cara-cara yang santun dan bermoral. Namun kecenderungan orang sebagai pelaku penipuan atau perampasan menginginkan kehidupan yang lebih baik tetapi melakukan tindak kejahatan yang dilakukan secara singkat, potong kompas, serba ingin instan. Penipuan dan perampasan jika masyarakatnya membiarkan berbuat seperti, tidak ada sanksi, maka di masa-masa yang akan datang tindakan menipu dan merampas bisa menjadi tindakan merampok.

3) Kekerasan

Kekerasan merupakan bentuk penganiayaan atau penyiksaan, dengan penggunaan kekuatan fisik dan kekuasaan, ancaman atau tindakan terhadap diri sendiri, perorangan atau sekelompok orang atau masyarakat yang mengakibatkan atau kemungkinan besar mengakibatkan memar/trauma, kematian, kerugian psikologis, kelainan perkembangan atau perampasan hak. Kekerasan dapat berupa kekerasan fisik, emosional, kekerasan secara verbal, kekerasan seksual, dsb., yang wujud kekerasannya bisa di sektor domestik (misalnya kekerasan dalam rumah tangga) atau kekerasan di sektor publik.

4) Trafficking

Trafficking atau perdagangan anak/perempuan saat ini banyak 
menghiasi berita. Angka tindakan trafficking meningkat, dengan banyak faktor yang menjadi penyebabnya. Para TKI/TKW yang dijanjikan akan mendapat pekerjaan dan upah yang tinggi baik di negeri sendiri maupun di negeri orang, tidak semua akan mendapatkan haknya sesuai janji. Perempuan tertipu menjadi korban trafficking, karena mereka tergiur untuk mendapatkan gaji yang tinggi. Anak-anak menjadi korban trafficking untuk dimanfaatkan dalam hal-hal yang tidak terpuji. Bisa juga terjadi penjualan organ vital manusia untuk mendapatkan keuntungan sebesar-besarnya.

Tindakan trafficking merupakan salah satu tindak kejahatan karena si pelaku hanya mempertimbangkan self-interest tanpa diimbangi dengan social-interest. Pelaku lebih mengutamakan hasrat mendapat keuntungan sebesar-besarnya dengan memanfaatkan korban, karena target usahanya lebih banyak mengambil orangorang dari kelompok masyarakat tidak mampu.

5) Korupsi

Fenomena korupsi seperti di Indonesia membuat dunia memberi predikat bangsa Indonesia sebagai negara terbanyak korupsinya. Ironisnya korupsi dilakukan oleh pejabat-pejabat negara yang sudah mendapat kepercayaan rakyat. Disebabkan oleh begitu banyaknya kasus korupsi, mengakibatkan terjadinya distrust masyarakat kepada wakil-wakilnya. Korupsi yang dilakukan lebih dominan dimotivasi oleh faktor ekonomi, seperti memperkaya diri, pencucian uang, mumpung ada kesempatan, dll.

\section{HOMO ECONOMICUS}

Istilah Homo economicus dipahami oleh masyarakat awam sebagai predikat bagi mereka kaum yang sangat mendewakan materi, mempunyai orientasi keuntungan pribadi, sehingga istilah ini kemudian bukan merupakan terminologi yang positif dalam kehidupan masyarakat. Satria Anandita (2007: 1) menguraikan asal kata homo economicus sebagai berikut. Homo economicus berasal dari bahasa Latin yang berarti manusia ekonomi. Apabila pengertian kata "ekonomi" sendiri dipahami dengan lebih mendalam, maka akan ditemukan arti Homo econo- 
micus tidak seperti yang selama ini orang awam secara sempit dipahami, melainkan akan merujuk kepada sebuah sosok manusia yang rasional dan berkebebasan dalam menentukan pilihan-pilihan yang ada untuk mencapai tujuan tertentu.

Homo Economicus biasanya dilawankan dengan Homo Socius. Homo Socius artinya manusia sebagai makhluk sosial, yang dapat hidup bermasyarakat, bukan seperti binatang yang bergerombol yang hanya mengenal hukum rimba, yaitu yang kuat yang berkuasa. Manusia bermasyarakat diatur dengan tata tertib demi kepentingan bersama. Dalam masyarakat manusia terjadi tindakan tolong-menolong. Dengan tindakan itu, walaupun fisiknya relatif lemah, tetapi dengan kemampuan nalar yang panjang tujuan-tujuan bermasyarakat dapat dicapai.

Manusia sebagai Homo Economicus berarti manusia dapat mengadakan usaha atas dasar perhitungan ekonomi (homo economicus). Salah satu prinsip dalam hukum ekonomi adalah, bahwa semua kegiatan harus atas dasar untung-rugi, untung apabila input lebih besar daripada output, rugi apabila sebaliknya. Manusia dalam tingkat sederhana dapat mencukupi kebutuhannya sendiri, kemudian atas dasar jasa maka dikembangkan sistem pasar sehingga hasil produksinya dijual di pasaran. Semakin luas pemasaran barang semakin banyak diperoleh keuntungan. Salah satu usaha meningkatkan produktivitas kerja dapat dijalankan dengan mempergunakan teknologi modern sehingga dapat ditingkatkan produktivitas kerja manusia.

Pengertian tentang Homo Economicus dalam ranah ekonomi memang dipahami sangat kuantitatif, menyangkut untung-rugi secara ekonomi, namun sesungguhnya, pengertian tesis ini sangat mendalam, yakni menyangkut tentang tendensi perilaku manusia yang mengarah kepada keuntungan pribadi dengan mengesampingkan kedudukannya sebagai anggota masyarakat atau dikenal dalam tesis Homo Socius. Keuntungan yang secara kuantitatif dalam ranah ekonomi dipahami sebagai profit, secara kualitatif keuntungan itu akan dirasakan sebagai kepuasan, entah bentuk tindakan itu baik atau buruk secara norma sosial dan norma lainnya.

Elizabeth Anderson (2000: 2) menulis tentang perkembangan baru dalam teori norma sosial. Teori sosial sekarang ini menawarkan tiga 
cara dalam menjelaskan mengapa masyarakat tunduk pada normanorma sosial. Pertama, teori pilihan rasional menggunakan pendekatan Homo economicus. Teori ini menjelaskan perilaku dalam kesesuaiannya dengan norma sosial sebagai hasil cara interaksi rasional secara instrumental, sebagai suatu kepentingan diri sendiri.

Kedua, teori evolusi menggunakan pendekatan evolusi biologi dan budaya. Teori ini menjelaskan kesesuaian norma sosial sebagai ekspresi yang diwariskan secara turun-temurun atau ciri budaya yang memiliki perbedaan keberhasilan dalam meniru diri mereka karena beberapa proses selektif.

Ketiga, pendekatan Homo Socius. Teori ini menjelaskan kesesuaian norma sosial dalam batas-batas aturan yang bersifat normatif, dan sebab-sebab kenormatifan dalam cara-cara individu melihat norma sebagai ekspresi identitas sosial mereka secara penuh makna, hubungan mereka dengan masyarakat yang lain, atau tujuan bersama dan nilainilai.

Tiga cara ini masing-masing mengandung sebuah hubungan yang berbeda dengan sudut pandang wakil. Teori evolusi mengambil sudut pandang eksternal untuk wakil. Sebuah norma dapat menyebar karena tekanan selektif yang bekerja secara bebas apapun yang mereka anut melihat sebagai pengikat mereka untuk menaatinya. Secara rasional masyarakat menjelaskan norma sosial dari sudut pandang penganut mereka sendiri. Pada pandangan ini, hampir kebanyakan masyarakat telah terinternalisasi norma dan akan menaatinya oleh karena kenormatifannya, bagian dari sanksi yang melekat padanya. Teori pilihan rasional bersifat individual sebagaimana mengambil sikap yang lebih terasing terhadap norma sosial. Meskipun mereka mungkin tahu bahwa kesesuaian umum menjadi sebuah norma yang diidamkan, ini tidak memberi mereka dengan alasan untuk sesuai, sepanjang kesesuaian pribadi, pada jaringan, sangat berharga bagi setiap wakil.

Jadi, manusia dalam kehidupan bermasyarakat memiliki etika dalam berinteraksi antara yang satu dengan lainnya, tidak melihat kecil, dewasa, dan tua manusia itu, mulai dari perilaku, kesopanan, tingkah laku maupun komunikasi. Manusia dalam hal ini sudah mempunyai bekal perilaku yang tertanam saat ia dilahirkan, dari perilaku ter- 
sebut nantinya akan berkembang selaras dengan pertumbuhannya. Manusia juga mempunyai aturan/pedoman dalam kehidupan bermasyarakat. Aturan dalam bahasa yunani kuno disebut nomos. Tanpa adanya aturan dalam diri manusia maka kehidupan mereka dalam kesehariannya pasti tidak akan terkendali dan tidak mempunyai arah tujuan hidupnya ke depan.

Dikarenakan oleh berbeda-beda dalam setiap tujuan berinteraksi, manusia secara tidak sadar menjadi korban bagi manusia yang lain. Tesis yang mengatakan manusia sebagai Homo Homini Lupus adalah gambaran betapa manusia bisa memperlakukan manusia yang lain sebagai instrumen dalam mencapai tujuannya. Misalnya, maraknya penculikan, pembunuhan, mutilasi, premanisme yang mewabah, pencurian maupun tindak kejahatan lainnya di suatu negara. Hal tersebut mencerminkan manusia sewaktu-waktu dapat berubah menjadi buas seperti serigala jika dalam dirinya terdapat rasa tidak puas, iri, benci dengan manusia lainnya yang disebabkan oleh kemalasan dan tidak mau berusaha untuk sesuatu yang diinginkan. Manusia dalam hal ini melakukan tindakan tersebut juga karena ambisi dan hawa nafsu yang tidak dilandasi dengan aturan hidup yang benar, sehingga mereka melakukan tindakan yang tidak seharusnya dilakukan dalam bermasyarakat.

Sebagai makhluk sosial mestinya setiap individu dapat saling mengisi kekurangan yang lain dari kelebihan yang dimiliki, begitu sebaliknya. Setiap manusia memiliki ciri khas yang berbeda seperti bentuk fisik, bakat, dan kemampuannya. Perbedaan-perbedaan ciri khas tersebut mengakibatkan setiap manusia bisa saling mengisi dan saling membutuhkan satu sama lain.

Homo Economicus sebenarnya menegaskan bahwa manusia memiliki kebutuhan yang beragam dan tidak pernah merasa puas. Manusia memiliki sifat untuk senantiasa memperbaiki dan meningkatkan kualitas dalam hidupnya. Artinya manusia sebagai makhluk ekonomi bersikap rasional, segala perilaku dan kegiatannya selalu memperhitungkan keuntungan yang diperoleh.

Ada karakteristik yang biasanya dimiliki oleh manusia dalam kedudukannya sebagai homo economicus, yaitu: 
a. Selalu bertindak secara rasional dengan mempertimbangkan antara pengorbanan dengan hasil yang diperoleh.

b. Memiliki rasa ketidakpuasan yang tidak terbatas.

c. Selalu berusaha untuk mendapatkan yang terbaik dengan menjunjung norma agama, adat istiadat, dan norma yang berlaku di masyarakat.

d. Bertindak berdasarkan dorongan pada kepentingan sendiri untuk memenuhi kebutuhannya secara efisien.

e. Cenderung memilih suatu kegiatan/aktivitas yang paling dekat dengan pencapaian tujuan yang diinginkan.

Jika memperhatikan karakteristik manusia sebagai homo economicus seperti tersebut di atas, maka sangat wajar jika seseorang melakukan suatu tindakan yang secara rasional mencari keuntungan baik secara kuantitatif maupun kualitatif. Kenyataannya, tidak semua demikian. Contoh manusia dalam suatu masyarakat yang melakukan suatu tindakan mencuri, membunuh, memperkosa, korupsi, dan sebagainya, merupakan suatu tindakan yang walaupun terdapat tendensi keuntungan (utility) pribadi, namun tindakan tersebut tidak sesuai dengan norma-norma yang telah disepakati. Oleh karena itu, pengertian homo economicus saat ini telah bergeser akibat dari munculnya fenomena yang telah memelintir substansi homo economicus sendiri.

Homo economicus dapat dilawankan juga dengan pengertian tentang hubungan yang komplementer dalam suatu masyarakat. Setiap individu terbentuk suatu hubungan resiproksal dengan individu yang lain, karena didasari suatu pemahaman bahwa setiap individu adalah unik, memiliki kelemahan dan kelebihan yang tidak sama. Oleh karenanya, demi suatu bangunan kehidupan sosial yang harmonis, maka hubungan yang resiproksal itulah yang menjadi gambaran idela dalam suatu kehidupan bersama. Homo economicus seperti yang dipahami saat ini akan berbahaya karena justru akan memperbanyak tindakan-tindakan yang tidak sesuai dengan konsensus norma yang dibangun dan dipertahankan secara turun-temurun, kemudian akan meruntuhkan rasa saling membutuhkan, karena individu lain hanya akan menjadi instrumen bagi kepentingan pibadi. Ini akan berbahaya jika sampai 
pada tindakan-tindakan yang berpotensi pada pelanggaran nilai-nilai kemanusiaan.

\section{SIMPULAN}

Idealnya setiap manusia dapat melakukan tindakan dalam dwi fungsinya sebagai makhluk individu sekaligus sebagai makhluk sosial. Keseimbangan dwi fungsi ini sesungguhnya menjadi bantalan bagi bangunan keharmonisan dalam kehidupan suatu masyarakat. Jika terjadi kepincangan, apalagi kecenderungan individu menonjolkan posisi sebagai makhluk individu maka bangunan kehidupan bersama dapat menjadi seperti yang digambarkan dalam homo homini lupus, padahal membangun suatu masyarakat yang harmonis harus didukung dengan kehidupan bersama, saling membutuhkan, dan saling memberi.

Tindakan kejahatan di Indonesia seperti pembunuhan, korupsi, trafficking, dan sebagainya, merupakan fakta betapa kehidupan di Indonesia sudah dibayang-bayangi oleh kepentingan pribadi yang sangat menonjol. Kepentingan pribadi yang lebih didominasi oleh faktor ekonomi menjadi pengaruh besar dalam kecenderungan tindakan kejahatan. Kecenderungan manusia Indonesia lebih menekankan aspek sosialitasnya, namun ternyata fakta membuktikan bahwa kecenderungan itu sudah mulai memudar, meskipun tidak semua manusia Indonesia melakukan tindak kejahatan. Setidaknya, homo economicus dalam pengertian manusia ekonomi yang senantiasa menekankan aspek keuntungan dalam setiap tindakannya dapat menjadi alat uji dalam realitas kehidupan bangsa Indonesia.

Homo economicus benar-benar dipahami dalam suatu tindakan yang kontradiktif dengan pengertian homo Socius. Homo economicus jika tidak dikendalikan akan membawa manusia dalam suatu situasi "berperang" sepertigambaran homo hominilupus.

\section{DAFTAR PUSTAKA}

Agustian, Iin, t.t., Tindakan Seseorang Melakukan Keinginan, dalam www.scribd.com/doc/119278097/Motif diunduh tanggal 19 Oktober 2013.

Anandita, Satria, 2007, Homo Economicus, dalam satria.anandita.net/ 
homo-economicus diunduh tanggal 26 Oktober 2013.

Anderson, Elizabeth, 2000, Beyond Homo economicus: New Developments in Theories of Social Norms, Philosophy and Public Affairs Vol. 29 No. 2 (Spring 2000), Blackwell Publishing, dalam http://www.jstor.org/stable/2672816 diakses tanggal 22 Juni 2009.

Anonim, t.t, dalam http://www.i2harmony.info/tiga-pembunuh-berla tar-belakang-kelainan-orientasi-seksual.html) diunduh tanggal 11 Maret 2013.

Armandhanu, Deny, 2013, Sang Ibu Bentuk Adam Lanza Jadi Pembunuh?Dengan senapan ibunya, dia membunuh 26 orang, kebanyakan bocah, dalam http://dunia.news.viva.co.id/news/re ad/375610-sang-ibu-bentuk-adam-lanza-jadi-pembunuhdiunduh tanggal 11 Maret 2013.

Bakker, Anton dan Achmad Charris Zubair, 1994, Metodologi Penelitian Filsafat, Penerbit Kanisius, Yogyakarta.

Hoetaoeroek, Alfred, 1961, Garis Besar Tata hukum Indonesia, Erlangga, Djakarta.

Kardi, Dika Dania, 2012, Orang melakukan Kejahatan Bukan untuk Balas Dendam, Jurnal Biologi Letters dalam http://www.infogue. com/viewstory/2012/07/20/hasil_penelitian_orang_lakuka n_kejahatan_bukan_untuk_balas_dendam/?url=http://m. mediaindonesia.com/index.php/read/2012/07/20/334499/29 1/7/Hasil_Penelitian_Orang_Lakukan_Kejahatan_bukan_u ntuk_Balas_Dendam, diunduh tanggal 24 November 2012.

Kiranawati, 2008, Pengertian-pengertian Hak Asasi Manusia, dalam gurupkn.wordpress.com/2008/02/22/pengertianpengertian-hak-asasi-manusia/ diunduh tanggal 10 Oktober 2013.

Leahy Louis, 2001, Siapakah Manusia? Sintesis filosofis tentang manusia, Penerbit Kanisius, Yogyakarta.

Maharani, Septiana Dwiputri, 2007, Fenomena Bunuh Diri Tinjauan Filsafat Manusia, Studi Kasus Bunuh Diri Ibu dan anak, Jurnal Filsafat “Wisdom" vol.17 nomor 1. A pril 2007 ISSN: 0853-1870. 2009, Filsafat Manusia, Unsur-unsur dan 
Problematikanya, Penerbit KEPEL, Yogyakarta.

Maharani, Septiana Dwiputri, 2011, Pandangan Gabriel Marcel Mengenai Manusia, Laporan Penelitian dibiayai dengan Dana Masyarakat Fakultas Filsafat UGM tahun 2011.

2012, Kepedulian terhadap Kemiskinan dalam Perspektif Filsafat Manusia, Laporan Penelitian dibiayai dengan Dana Masyarakat Fakultas Filsafat UGM tahun 2012.

2012, Kejahatan Korupsi dalam Perspektif

Filsafat Manusia, Penelitian Filsafat dibiayai dengan dana DIPAAPBN-P Fakultas Filsafat UGM tahun anggaran 2012.

Marbusan, 2011, Motif Kemanusiaan Manusia, dalam psikologiindo nesia.blogspot.com/2011/05/motif-kemanusiaan manusia.html diunduh tanggal 28 Oktober 2013.

Oktavian, Arie, 2013., Hubungan Tindak Kejahatan dengan Tingkat Ekonomi, dalam artaviean.blogspot.com/2013/05/hubungantindak-kejahatan-denga-tingkat.html diunduh tanggal 14 Oktober 2013.

Ramdhany, Wahyu, 2011, Pengertian Kejahatan, dalam wahyoeartikel. blogspot.com/2011/12/manusia-adalah-makhluk-sosialyang.html diunduh tanggal 9 Oktober 2013.

Sidik Doedireja, 1955, Kriminalitas, Pelita, Bogor.

Soesilo, R., 1985, Kitab Undang-Undang Hukum Pidana serta Komentarkomentar Lengkap Pasal Demi Pasal, Penerbit Politeia.

Triacute, t.t., Tindakan, Motif, dan Prinsip Ekonomi, dalam www.scribd. com/doc/23597612/Tindakan-Motif-Dan-Prinsip-Ekonomi diunduh tanggal 19 Oktober 2013.

W.J.S. Poerwadarminta, 1978, Kamus Umum Bahasa Indonesia, Cetakan IV, Balai Pustaka, Jakarta.

Yani, Dwi, 2012, Definisi Arti Kejahatan, dalam hukum-dan-umum.blog spot.com/2012/04/definisi-arti-kejahatan.html diunduh tgl 15 Oktober 2013.

Zaiah Daradjat, 1985, Membina Nilai-Nilai Moral di Indonesia, Cet. IV, PT. Bulan Bintang, Jakarta. 